\title{
Comparative Studies on ATP Production from Adenosine by a Methanol Yeast
}

\author{
Tetsu Yonehara* and Yoshiki Tani \\ Research Center for Cell and Tissue Culture, Kyoto University, \\ Kyoto 606, Japan \\ Received August 30, 1985
}

\begin{abstract}
An ATP production system involving the oxidation of methanol, oxidative phosphorylation of ADP and phosphorylation of adenosine with sorbitol-treated cells of Candida boidinii (Kloeckera sp.) No. 2201 was studied with regard to the metabolism of adenosine and the role of sorbitol.

Analysis by high performance liquid chromatography showed the accumulation of IMP in the reaction mixture, possibly due to catalysis by AMP deaminase. The efficiency of energy conversion from methanol to nucleotides was improved $30 \%$ by preventing the evaporation of methanol. Among osmoregulatory compounds that plasmolyzed the yeast cells, only sorbitol caused high ATP production activity on addition to the reaction mixture. The sorbitol effect was attributed to the supplying of NADH by the oxidation in parallel with the methanol oxidation.

The ability of ATP production from adenine and adenosine was found in many methanol yeasts belonging to the genera, Hansenula, Pichia, Candida and Torulopsis. C. boidinii had especially high ability to accumulate ATP from adenosine.
\end{abstract}

In the course of investigations concerned with the industrial application of methylotrophs, we developed an ATP production system, from AMP, ${ }^{1 \sim 3)}$ adenosine ${ }^{4)}$ or adenine, ${ }^{4)}$ using cells of a methanol yeast, Candida boidinii (Kloeckera sp.) No. 2201. The system involves the oxidation of methanol to reduce $\mathrm{NAD}^{+}$, the oxidative phosphorylation of ADP and the salvage synthesis of ADP. Efficient ATP accumulation was achieved from $\mathrm{AMP}^{3)}$ and adenosine $^{4)}$ with sorbitol-treated cells with conversion rates of $70 \%$ and $60 \%$, respectively.

In this study, we investigated the ATP production system of $C$. boidinii No. 2201 with regard to the metabolism of adenosine as a substrate and the role of sorbitol, and detected the ATP-producing activity in other methanol yeasts.

\section{MATERIALS AND METHODS}

Strains and chemicals. C. boidinii No. 2201, C. boidinii S-
1, C. boidinii S-2, Candida sp. 25-A, Candida sp. 1-A and Saccharomyces sake used were strains stored in our laboratory. Other yeasts were kindly supplied by the follwing; Saccharomyces sp. H-1 and Candida sp. N-16 from the Fermentation Research Institute, Ibaraki, Hansenula capsulata, H. nonfermentans, H. glucozyma, Pichia trehalophila, P. halophila, P. pastoris, Candida cariosilignicola, C. succiphila, C. lipolytica, Torulopsis pinus and T. glabrata from the Institute for Fermentation, Osaka, Hansenula polymorpha from Dr. Cooney, Massachusetts Institue of Technology, U.S.A., Candida boidinii from Dr. Sahm, (formerly) Gesellschaft für Molekularbiologische Forschung, West Germany, Hansenula ofunaensis and Torulopsis nagoyaensis from Mitsui Toatsu Chemicals Inc., Yokohama, Pichia aganobii from Mitsuibishi Gas Chemical Co. Inc., Niigata, and Candida methanolica and Torulopsis methanolovescens from Sanraku Ocean Co., Ltd., Fujisawa. Cultivations were performed as described previously. ${ }^{4)}$ All chemicals were obtained from usual commercial sources and used without further purification.

Preparation of sorbitol-treated cells. Washed and sorbitol-treated cells were prepared as described previously. $^{2)}$

Assay system for ATP production. The standard reaction mixture contained $25 \mu \mathrm{mol} \mathrm{K}_{2} \mathrm{HPO}_{4}, 50 \mu \mathrm{mol} \mathrm{Na} \mathrm{P}_{2} \mathrm{O}_{7}$.

* On leave from Toray Industries, Inc., Nagoya 455-91, Japan. 
$10 \mathrm{H}_{2} \mathrm{O}, 20 \mu \mathrm{mol}$ adenosine, $5 \mu \mathrm{mol} \mathrm{NAD}^{+}, 5 \mu \mathrm{mol}$ reduced glutathione (GSH), $500 \mu \mathrm{mol}$ methanol, $40 \mu \mathrm{mol}$ $\mathrm{MgSO}_{4} \cdot 7 \mathrm{H}_{2} \mathrm{O}, 300^{\circ} \mu \mathrm{mol}$ sorbitol and $10 \mathrm{mg}$, as dry weight, of sorbitol-treated cells of $C$. boidinii No. 2201 in a total volume of $0.5 \mathrm{ml}$. The reaction was carried out and terminated as described previously. ${ }^{4}$

The air-sealed reaction was initiated by addition of $0.2 \mathrm{ml}$ cell suspension containing $300 \mu \mathrm{mol}$ sorbitol, followed by shaking obliquely in a $21-\mathrm{mm} \phi$ test tube containing $70 \mathrm{ml}$ of air and sealed with a double rubber stopper. Other conditions were the same as the standard conditions.

When the activity was compared between different yeasts, the reaction mixtures contained $150 \mu$ mol potassium phosphate buffer ( $\mathrm{pH} 7.3$ ), $20 \mu \mathrm{mol}$ adenosine or $5 \mu \mathrm{mol}$ adenine, $0.5 \mu \mathrm{mol} \mathrm{NAD}^{+}, 1.5 \mu \mathrm{mol} \mathrm{ATP}, 40 \mu \mathrm{mol}$ $\mathrm{MgSO} \cdot 7 \mathrm{H}_{2} \mathrm{O}, 500 \mu \mathrm{mol}$ methanol, $300 \mu \mathrm{mol}$ sorbitol and $10 \mathrm{mg}$, as dry weight, of sorbitol-treated cells of each yeast in a total volume of $0.5 \mathrm{ml}$. Other conditions were the same as the standard conditions.

Analyses. All analyses were carried out with the supernatants of the reaction mixtures, prepared as described previously. ${ }^{4)}$ ATP, ADP and AMP were analyzed by the enzymatic methods described previously ${ }^{4}$ or by high performance liquid chromatography (HPLC). Other nucleotidic compounds were analyzed by HPLC.

HPLC was carried out with a Hitachi liquid chromatograph system 655 under the following conditions: column, M\&S PACK C18 $(4.6 \mathrm{~mm}$ i.d. $\times 150 \mathrm{~mm})$; mobile phase, $0.2 \mathrm{M}$ potassium phosphate buffer, $\mathrm{pH} 6.0$ (solvent $\mathrm{A}$ ), and methanol (solvent B); gradient, $2 \%$ of solvent $\mathrm{B}(0 \sim$ $6 \mathrm{~min})$ and $10 \%$ of solvent $\mathrm{B}(6 \sim 20 \mathrm{~min})$; flow rate, $1.0 \mathrm{mi} / \mathrm{min}$; injection volume, $5 \mu \mathrm{l}$; detection, UV $(260 \mathrm{~nm})$.

Methanol consumption was determined by gas chromatography as described previously. ${ }^{4)}$

Sorbitol was analyzed by the enzymatic method with sorbitol dehydrogenase. ${ }^{5)}$

\section{RESULTS AND DISCUSSION}

\section{HPLC analysis of the reaction mixture for ATP production}

The decrease in the total amount of adenine nucleotides in the reaction mixture with cells of C. boidinii No. 2201 was determined by differential enzymatic analyses of ATP, ADP and AMP. To determine the overall metabolism of the substrate, adenosine, is essential for the characterization of the ATP-producing system. Therefore, we developed an HPLC method for determining all nucleotidic compounds found in the reaction mixture. The HPLC method described under MATERIALS

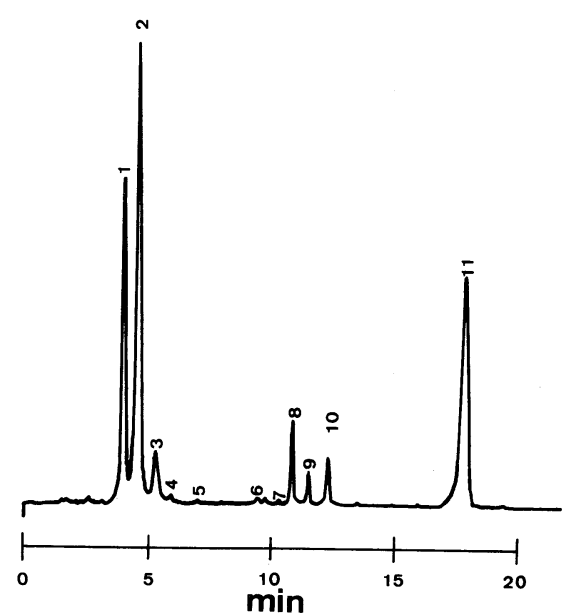

FIG. 1. High Performance Liquid Chromatography of the Adenosine Phosphorylation Reaction Mixture.

The reaction mixture was analyzed as described under MATERIALS AND Methods. Elution order: peak 1, IMP; peak 2, ATP; peak 3, ADP; peak 4, hypoxanthine; peak 5, xanthine; peak 6, AMP; peak 7, adenine; peak $8, \mathrm{NAD}^{+}$; peak 9 , inosine; peak 10 , NADH; peak 11, adenosine.

AND Methods made the simultaneous analysis of nucleotidic compounds possible. Figure 1 shows a chromatogram of a reaction mixture with $C$. boidinii No. 2201 cells, in which ATP, ADP, AMP, adenosine, adenine, IMP, inosine, hypoxanthine, xanthine, NAD ${ }^{+}$ and NADH were detected. The amount of each adenine nucleotide determined on HPLC analysis was confirmed to coincide with the enzymatic value.

\section{Metabolism of adenosine in the ATP-producing reaction}

Figure 2 shows a typical time course of ATP production by $C$. boidinii No. 2201 cells under the standard reaction conditions. ATP increased rather gradually as compared with adenosine consumption until 10-hr incubation. AMP and ADP were not found in the reaction mixture. This might show that the activity of adenosine kinase is rate-limiting for the production of ATP at this stage. At $10 \sim 14-\mathrm{hr}$ incubation, AMP and ADP appeared, and total amount of adenine nucleotides coincided with that of adenosine consumed. After 14-hr incubation, IMP appeared and increased 


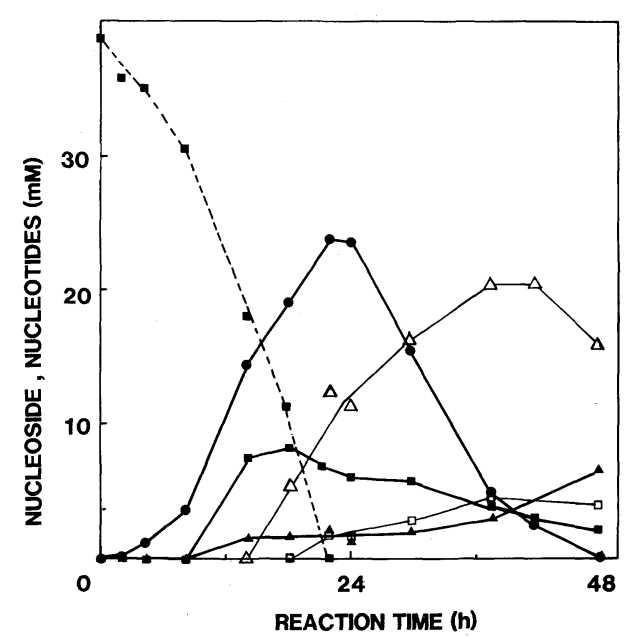

FIG. 2. Time Course of Adenosine Metabolism under the Standard Reaction Conditions.

The reaction was carried out as described in the text as the established method: - - - ATP; - - - ADP; - - AMP; -- -- , adenosine; - $\triangle-$, IMP; - $\square-$, inosine.

rapidly. ATP accumulation continued until $22 \mathrm{hr}$. Further incubation increased the amounts of IMP and inosine.

No inosine appeared until $40 \mathrm{~mm}$ adenosine had disappeared. The total amount of ATP, ADP, AMP, adenosine, IMP and inosine always remained constant at $40 \mathrm{~mm}$ until $40-\mathrm{hr}$ incubation.

From the results, it was concluded that the degradation of adenine nucleotides might be due to the activity of AMP deaminase and not to that of adenosine deaminase or adenine deaminase.

\section{Efficiency of energy conversion from methanol}

In previous studies, ${ }^{3,4)}$ we investigated and discussed the energy efficiency of the ATP production system with $C$. boidinii No. 2201 cells, which use methanol as an energy source, and the theoretical value, $\mathrm{Ke}(t)$, for the conversion of adenosine to ATP was estimated to be $14.3 \%{ }^{4}$ ) The ratio of the practical energy efficiency, $\operatorname{Ke}(p)$, against the theoretical efficiency was only $2.2 \%$, even though it included the energy of phosphate bonds of AMP and ADP besides ATP. ${ }^{4)}$ Here, we estimated the amounts of not only adenine nucleotides but also that of IMP as energy stored compounds in the reaction mixture. Furthermore, the evaporation of methanol from the reaction mixture was prevented by the air-sealed system.

Table I shows the amounts of consumption of methanol and phosphorylation of adenosine in the reaction mixture. The practical energy efficiency against the methanol consumption expressed as follows,

$$
\mathrm{Ke}(p)=(2,181 / 51,302) \times 100=4.25 \%
$$

The ratio of the practical efficiency against the theoretical efficiency expressed as follows,

$$
\begin{aligned}
\mathrm{K} e & =(\mathrm{K} e(p) / \mathrm{K} e(t)) \times 100 \\
& =(4.25 / 14.3) \times 100=30 \%
\end{aligned}
$$

These values seem to be more reasonable compared with the previous ones. ${ }^{4}$

\section{Role of sorbitol in the ATP-producing system}

The function of sorbitol in the ATP production system, from AMP, might be to make and maintain the plasma-membrane of $C$. boidinii No. 2201 cells permeable to nucleotidic compounds. $^{2)}$ Some osmoregulatory compounds other than sorbitol could also be used during the preparation of plasmolyzed cells. These compounds, however, could not replace sorbitol in the ATP-producing reaction. This suggests that sorbitol has another function in the reaction mixture.

1) Treatment of cells with sorbitol. Table II shows the effect of each step in the preparation of sorbitol-treated cells on the ATP-producing activity. The treatment at $37^{\circ} \mathrm{C}$ before and after sorbitol addition could be replaced by a cold shock at $-80^{\circ} \mathrm{C}$. The addition of sorbitol was essential for the ATP-producing activity. Thus, the heat treatment might enhance the function of sorbitol in a kind of plasmolysis of the yeast cells.

2) Replacement of sorbitol by other osmoregulatory compounds. We tested other osmoregulatory compounds in the same way as sorbitol as to both cell treatment and ATP production. As shown in Table III, these compounds other than sorbitol could not make 
Table I. Energy Balance of Adenosine Phosphorylation

\begin{tabular}{|c|c|c|c|c|}
\hline $\begin{array}{l}\text { Energy source \& } \\
\text { product }\end{array}$ & $\begin{array}{l}\text { Concn. } \\
(\mathrm{mm})\end{array}$ & Reaction & $\begin{array}{c}\Delta G \\
(\mathrm{KJ} / \mathrm{mol})\end{array}$ & $\begin{array}{c}\Delta G \\
(J / \text { liter })\end{array}$ \\
\hline Methanol consumed & 73 & Methanol $\rightarrow \mathrm{CO}_{2}$ & -702.8 & $-51,302$ \\
\hline ATP produced & 21.5 & Adenosine $\rightarrow$ ATP & 75.3 & 1,620 \\
\hline ADP produced & 8.3 & Adenosine $\rightarrow$ ADP & 44.8 & 373 \\
\hline AMP produced & 2.3 & Adenosine $\rightarrow$ AMP & 14.2 & 33 \\
\hline IMP produced & 10.9 & Adenosine $\rightarrow \mathrm{AMP} \rightarrow \mathrm{IMP}$ & $14.2^{a}$ & 155 \\
\hline $\begin{array}{l}\text { Energy-stored } \\
\text { phosphates (bound } \\
\text { in nucleotides) }\end{array}$ & 94.3 & & & 2,181 \\
\hline
\end{tabular}

a On the assumption that IMP has the same free energy as AMP.

Table II. EfFects of the Steps of Sorbitol

Treatment of $C$. boidinii No. 2201 Cell on Adenosine Phosphorylation Activity

The complete sorbitol treatment process ${ }^{2)}$ comprises 1) pre-heat treatment at $37^{\circ} \mathrm{C}$ for $45 \mathrm{~min}$, 2) addition of sorbitol to a final concentration of $1.5 \mathrm{M}$, and 3 ) heat treatment at $37^{\circ} \mathrm{C}$ for $10 \mathrm{~min}$. The treated cells could be stored at $-80^{\circ} \mathrm{C}$. The activity was determined under the standard reaction conditions. The reaction time was $24 \mathrm{hr}$.

\begin{tabular}{|c|c|c|c|c|}
\hline \multicolumn{4}{|c|}{ Step of treatment ${ }^{a}$} & \multirow{2}{*}{$\begin{array}{l}\text { Relativ } \\
\text { activity } \\
(\%)\end{array}$} \\
\hline $\begin{array}{l}\text { Pre-heat } \\
\text { treatment }\end{array}$ & $\begin{array}{l}\text { Sorbitol } \\
\text { addition }\end{array}$ & $\begin{array}{c}\text { Heat } \\
\text { treatment }\end{array}$ & $\begin{array}{c}\text { Stored at } \\
-80^{\circ} \mathrm{C}\end{array}$ & \\
\hline+ & + & + & - & 100 \\
\hline+ & + & + & + & 86.0 \\
\hline- & + & - & - & 1.0 \\
\hline- & + & - & + & 49.9 \\
\hline+ & - & + & + & 0 \\
\hline- & - & - & + & 0 \\
\hline
\end{tabular}

a - and + denote that the step was omitted and carried out, respectively.

$b$ The activity was expressed as the amount of total nucleotides including ATP, ADP, AMP and IMP.

yeast cells show a high phosphorylating activity in the reaction. The addition of high concentrations of sorbitol or other reagents caused the death of yeast cells. The results showed that the viability of the yeast after both cell treatment and ATP production was not necessary for the activity. On the other hand, fructose and glucose could make cells show a weak phosphorylating activity in the same way as sorbitol. Especially, $0.4 \mathrm{M}$ fructose showed $8.5 \%$ relative activity compared with $0.6 \mathrm{M}$ sorbitol in the reaction. This suggests that sorbitol plays another role in the reaction mixture.

3) Adenosine phosphorylation in a sorbitolcontaining reaction mixture. The probable other role of sorbitol in the reaction mixture was studied with the omissions and additions shown in Table IV. NAD ${ }^{+}$and air were essential not only for the phosphorylation of adenosine but also the consumption of sorbitol. Fructose and glucose, especially fructose, were converted to sorbitol during the reaction without sorbitol. These results indicate the presence of a $\mathrm{NAD}^{+}$-dependent sorbitol dehydrogenase in the yeast cells. Omission of methanol increased the consumption of sorbitol. Figure 3 shows that the activity of adenosine phosphorylation decreased with increasing methanol concentration over the optimum concentration, but the consumption of sorbitol decreased with increasing methanol concentration.

From the results mentioned above, it might be concluded that the concentrations of $\mathrm{NADH}$ and $\mathrm{NAD}^{+}$are balanced by coupling of $\mathrm{NAD}^{+}$-dependent oxidations of sorbitol to fructose and of methanol to $\mathrm{CO}_{2}$, and NADHdependent reduction of fructose to sorbitol. Thus, the additional role of sorbitol in the reaction mixture might be to control the amount of NADH in addition to osmoregulation (Fig. 4). 
Table III. Effects of Treatment with Osmoregulatory Compound on Cell Viability and Adenosine Phosphorylation

Cells of $C$. boidinii No. 2201 were treated as described in the text, replacing $1.5 \mathrm{M}$ sorbitol by each compound at the concentration indicated. The activity was determined under the standard reaction conditions except for the addition of each compound instead of sorbitol. The incubation time was $24 \mathrm{hr}$.

\begin{tabular}{|c|c|c|c|c|c|}
\hline \multirow[b]{2}{*}{ Compound } & \multicolumn{2}{|c|}{ Concentration in } & \multicolumn{2}{|c|}{ Cell viability $(\%)$} & \multirow{2}{*}{$\begin{array}{c}\text { Relative } \\
\text { activity }^{a} \\
(\%)\end{array}$} \\
\hline & $\begin{array}{c}\text { Cell } \\
\text { treatment }\end{array}$ & $\begin{array}{l}\text { Reaction } \\
\text { mixture }\end{array}$ & $\begin{array}{c}\text { Before } \\
\text { reaction }\end{array}$ & $\begin{array}{c}\text { After } \\
\text { reaction }\end{array}$ & \\
\hline None & & & 100 & 3.1 & 0 \\
\hline Sorbitol & $1.5 \mathrm{M}$ & $0.6 \mathrm{M}$ & 0.5 & 3.1 & 100 \\
\hline $\mathrm{KCl}$ & $1.5 \mathrm{M}$ & $0.6 \mathrm{M}$ & 0 & 0 & 0 \\
\hline $\mathrm{NaCl}$ & $1.5 \mathrm{M}$ & $0.6 \mathrm{M}$ & 0 & 0 & 0 \\
\hline Polyethylene & $10 \%$ & $4 \%$ & & & 0 \\
\hline \multirow[t]{2}{*}{ glycol \#4000 } & $15 \%$ & $6 \%$ & 20.7 & 4.7 & 0 \\
\hline & $30 \%$ & $12 \%$ & & & 0 \\
\hline \multirow[t]{3}{*}{ Ethylene glycol } & $1.0 \mathrm{M}$ & $0.4 \mathrm{M}$ & & & 0 \\
\hline & $1.5 \mathrm{M}$ & $0.6 \mathrm{M}$ & 6.3 & 3.1 & 0 \\
\hline & $3.0 \mathrm{M}$ & $1.2 \mathrm{M}$ & & & 0 \\
\hline Glycerol & $1.5 \mathrm{M}$ & $0.6 \mathrm{M}$ & 0.9 & 1.1 & 0 \\
\hline \multirow[t]{2}{*}{ Glucose } & $1.0 \mathrm{M}$ & $0.4 \mathrm{M}$ & & & 4.2 \\
\hline & $1.5 \mathrm{M}$ & $0.6 \mathrm{M}$ & 0.2 & 0.8 & 0 \\
\hline \multirow[t]{2}{*}{ Fructose } & $1.0 \mathrm{M}$ & $0.4 \mathrm{M}$ & & & 8.5 \\
\hline & $1.5 \mathrm{M}$ & $0.6 \mathrm{M}$ & 0 & 1.2 & 2.5 \\
\hline Saccharose & $0.75 \mathrm{M}$ & $0.3 \mathrm{M}$ & 1.8 & 3.6 & 0 \\
\hline Starch & $15 \%$ & $6 \%$ & 5.3 & 1.9 & 0 \\
\hline
\end{tabular}

a Activity is expressed as in Table II.

Table IV. Metabolism of Sorbitol in the Reaction Mixture

Cells of $C$. boidinii No. 2201 were treated as described in the text. The standard reaction conditions were used except for the concentration of each compound. The incubation time was $24 \mathrm{hr}$.

\begin{tabular}{|c|c|c|c|c|}
\hline \multicolumn{2}{|c|}{ Compound } & \multicolumn{2}{|c|}{ Sorbitol (mM) } & \multirow{2}{*}{$\begin{array}{c}\text { Relative activity }^{a} \\
(\%)\end{array}$} \\
\hline $\begin{array}{l}\text { Omitted from } \\
\text { reaction } \\
\text { mixture }\end{array}$ & $\begin{array}{l}\text { Added to } \\
\text { reaction } \\
\text { mixture }\end{array}$ & Consumed & Produced & \\
\hline None & None & 100.6 & 0 & 100 \\
\hline $\mathrm{NAD}^{+}$ & None & 4.1 & 0 & 2.1 \\
\hline Air & $\mathrm{N}_{2}$ & Trace & 0 & 0 \\
\hline Methanol & None & 303.0 & 0 & 35.5 \\
\hline Sorbitol & None & 0 & 0 & 0 \\
\hline Sorbitol & $0.6 \mathrm{M}$ fructose & 0 & 82.4 & 2.5 \\
\hline Sorbitol & $0.4 \mathrm{M}$ fructose & 0 & 44.2 & 8.5 \\
\hline Sorbitol & $0.6 \mathrm{M}$ glucose & 0 & 10.6 & 0 \\
\hline
\end{tabular}

a Activity is expressed as in Table II.

ATP productivity in methanol yeasts

So far, the ATP production system has been investigated only with C. boidinii No. 2201. The results, however, revealed that the activity should be common among methanol yeasts. Twenty-four strains of methanol yeasts were tested as to their ATP productivity. It was found that $\mathrm{NAD}^{+}$was gradually degraded to 


\section{Table V. ATP Productivity in Methanol Yeasts}

Cells of each yeast were treated as described in Table II. The reaction and ATP analysis were carried out as described under Materials AND Methods. The reaction time was $22 \mathrm{hr}$.

\begin{tabular}{|c|c|c|c|}
\hline \multirow{2}{*}{ Species } & \multirow{2}{*}{ Strain } & \multicolumn{2}{|c|}{ ATP produced from } \\
\hline & & Adenosine & (mM) Adenine \\
\hline \multicolumn{4}{|l|}{ (Ascomycetous yeasts) } \\
\hline Saccharomyces sp. H-1 & & 2.9 & 0.5 \\
\hline Hansenula capsulata & IFO 0974 & 16.0 & 3.8 \\
\hline nonfermentans & IFO 1473 & 3.9 & 1.7 \\
\hline polymorpha & & 1.0 & $\operatorname{tr}^{* *}$ \\
\hline ofunaensis & & 1.5 & $\operatorname{tr}$ \\
\hline glucozyma & IFO 1472 & $\operatorname{tr}$ & $\operatorname{tr}$ \\
\hline Pichia trehalophila & IFO 1683 & 1.6 & 1.2 \\
\hline aganobii $\mathrm{Y}-1023$ & & 11.8 & 1.7 \\
\hline halophila & IFO 0947 & $\operatorname{tr}$ & $\operatorname{tr}$ \\
\hline pastoris & IFO 0948 & 0.4 & $\operatorname{tr}$ \\
\hline Saccharomyces sake* & AKU 4111 & $\operatorname{tr}$ & $\operatorname{tr}$ \\
\hline \multicolumn{4}{|l|}{ (Asporogenous yeasts) } \\
\hline \multicolumn{4}{|l|}{ Candida boidinii } \\
\hline (Kloeckera sp.) No.2201 & AKU 4705 & 27.2 & 7.7 \\
\hline boidinii $\mathrm{S}-1$ & AKU 4614 & 17.5 & 4.8 \\
\hline boidinii S-2 & AKU 4615 & 11.9 & 3.2 \\
\hline boidinii & & 4.6 & 2.0 \\
\hline sp. N-16 & & 1.8 & $\operatorname{tr}$ \\
\hline sp. $25-\mathrm{A}$ & AKU 4621 & 21.8 & 2.3 \\
\hline sp. 1-A & AKU 4622 & 22.3 & 1.6 \\
\hline methanolica & ATCC 26175 & 12.3 & 2.3 \\
\hline cariosilignicola & IFO 1910 & 4.9 & 1.3 \\
\hline succiphila & IFO 1911 & 5.8 & 1.6 \\
\hline Torulopsis pinus & IFO 0741 & $\operatorname{tr}$ & $\operatorname{tr}$ \\
\hline pinus & IFO 1327 & 2.9 & 1.2 \\
\hline methanolovescens & ATCC 26176 & 10.0 & 2.3 \\
\hline nagoyaensis & & 3.1 & 1.6 \\
\hline glabrata & IFO 0005 & 2.1 & $\operatorname{tr}$ \\
\hline Candida lipolytica* & IFO 0717 & 1.7 & $\operatorname{tr}$ \\
\hline
\end{tabular}

* These yeasts were used as references.

** $\operatorname{tr}(0.1 \mathrm{mM})$.

supply ATP until 10-hr incubation and then recovered with the accumulation of more than $3 \mathrm{~mm}$ ATP under the standard reaction conditions with $C$. boidinii No. 2201 cells (unpublished data). This might cause errors on comparison of ATP productivity. Therefore, we compared the activity of these yeasts using the reaction conditions given under MATERIALS AND METHODS, under which the effect of the $\mathrm{NAD}^{+}$concentration on the activity was minimized.
As shown in Table V, significant activity of ATP production from $40 \mathrm{~mm}$ adenosine or $10 \mathrm{~mm}$ adenine was found in several strains of methanol yeasts, e.g. H. capsulata, P. aganobii, C. boidinii S-1, C. boidinii S-2, C. methanolica, T. methanolovescens and so on. Most strains belonging to the genus, Candida, showed high ability to produce ATP from adenosine. Among them, $C$. boidinii No. 2201 showed the highest productivity of ATP from not only adenosine but also adenine un- 


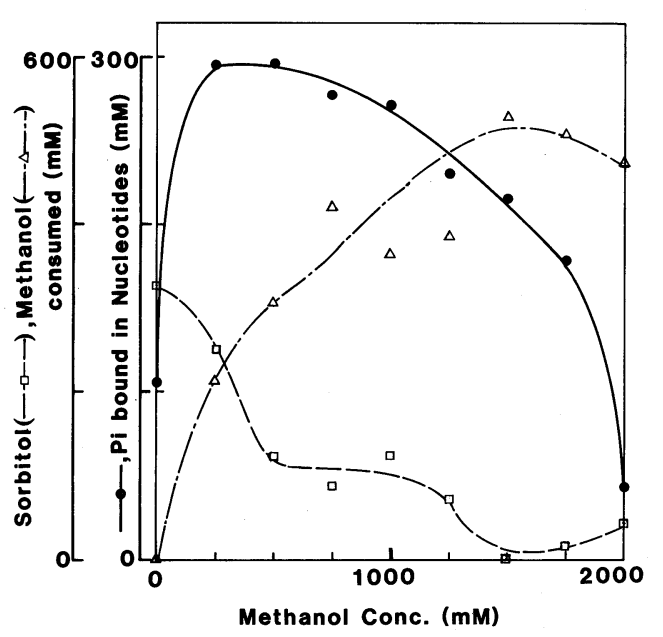

FIG. 3. Effect of Methanol on Energy Source Utilization.

The reaction was carried out with the air-sealed reaction system except for the concentration of methanol and the feeding of $150 \mathrm{~mm}$ potassium phosphate buffer $(\mathrm{pH} 7.3)$ at $15-\mathrm{hr}$ incubation. The incubation time was $26 \mathrm{hr}$.

der the conditions employed.

Acknowledgment. The authors wish to thank

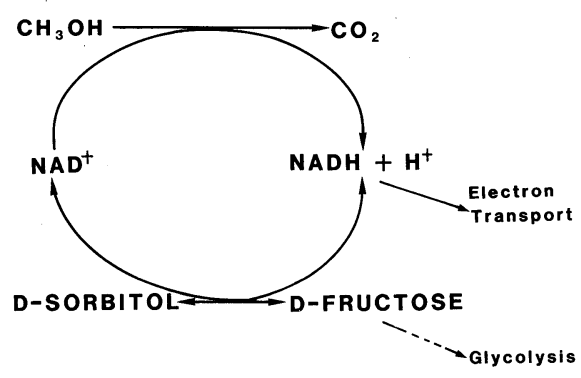

FIG. 4. Control System of the NADH Concentration by Sorbitol Dehydrogenase.

Professor H. Yamada, Kyoto University, for his encouragement during this study.

\section{REFERENCES}

1) Y. Tani, Y. Mitani and H. Yamada, Agric. Biol. Chem., 46, 1097 (1982).

2) Y. Tani, Y. Mitani and H. Yamada, J. Ferment. Technol., 62, 99 (1984).

3) Y. Tani, T. Yonehara, Y. Mitani and H. Yamada, $J$. Biotechnol., 1, 119 (1984).

4) Y. Tani and T. Yonehara, Agric. Biol. Chem., 49, 637 (1985).

5) H. G. Williams-Ashman and J. Banks, Arch. Biochem. Biophys., 50, 513 (1954). 